\title{
Hydrothermal Corrosion of Second Generation FeCrAl Alloys in Boiling Water Reactor Conditions
}

\section{Fuel Cycle Research \& Development Advanced Fuels Campaign}

SS Raiman

R Rebak (GE Global Research)

K Field

Y Yamamoto

KA Terrani

Prepared for

U. S. Department of Energy Office of Nuclear Energy 


\section{DISCLAIMER}

This information was prepared as an account of work sponsored by an agency of the U.S. Government. Neither the U.S. Government nor any agency thereof, nor any of their employees, makes any warranty,

expressed or implied, or assumes any legal liability or responsibility for the accuracy, completeness, or usefulness, of any information, apparatus, product, or process disclosed, or represents that its use would not infringe privately owned rights. References herein to any specific commercial product, process, or service by trade name, trade mark, manufacturer, or otherwise, does not necessarily constitute or imply its endorsement, recommendation, or favoring by the U.S. Government or any agency thereof. The views and opinions of authors expressed herein do not necessarily state or reflect those of the U.S. Government or any agency thereof. 


\title{
Hydrothermal Corrosion of Second Generation FeCrAl Alloys in Boiling Water Reactor Conditions
}

\author{
SS Raiman \\ R Rebak (GE Global Research) \\ K Field \\ Y Yamamoto \\ KA Terrani
}

February 2019

Prepared by

OAK RIDGE NATIONAL LABORATORY

Oak Ridge, TN 37831-6283

managed by

UT-BATTELLE, LLC

for the

US DEPARTMENT OF ENERGY

under contract DE-AC05-00OR22725 
INTENTIONALLY BLANK 


\section{ABSTRACT}

As part of an effort to develop advanced fuel cladding for use in light water reactors, several ORNLdeveloped $\mathrm{FeCrAl}$ alloys were tested in $\mathrm{BWR}$ conditions to determine their resistance to hydrothermal corrosion. Coupons with alloy compositions Fe-10Cr-6Al-2Mo, Fe-13Cr-5Al-2Mo, Fe-13Cr-6Al-2Mo, Fe-13Cr-7Al-2Mo, and Fe-13Cr-5Al-2Mo-1Nb were tested in BWR-NWC and BWR-HWC for 9 months in continuously refreshing autoclaves. Commercial APMT and Zircaloy-2 were also tested for comparison. Among samples exposed to HWC, Alloy C06M (10Cr-6Al) performed best, with a mass loss of $0.34 \mathrm{mg} / \mathrm{cm}^{2}$ over 9 months, and C037M performed worst with a mass loss of $1.2 \mathrm{mg} / \mathrm{cm}^{2}$ over 9 months. This mass loss was similar to Gen-1 FeCrAl alloys and represents an estimated annual thickness loss of approximately a few $\mu \mathrm{m}$ per year. Samples exposed to NWC had very small mass losses of less than $0.15 \mathrm{mg} / \mathrm{cm}^{2}$ or mass gains up to $0.05 \mathrm{mg} / \mathrm{cm}^{2}$. These represent very small annual losses in thickness. Based on the results of this testing, the Gen-2 FeCrAl alloys tested have suitable resistance to hydrothermal corrosion for use as fuel cladding in BWR-NWC and BWR-HWC conditions. 
INTENTIONALLY BLANK 


\section{CONTENTS}

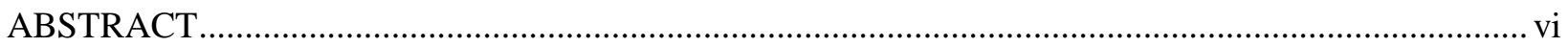

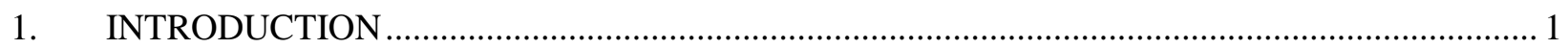

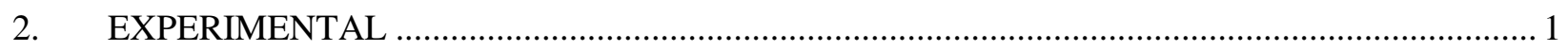

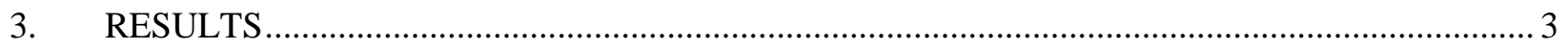

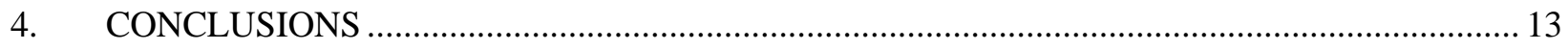

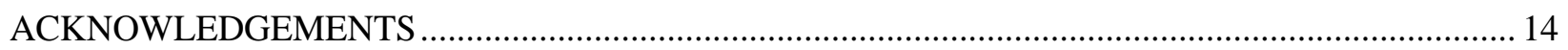

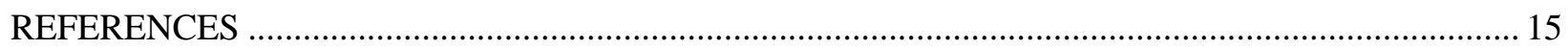

FIGURES

Figure 1. Drawing of the coupons used for autoclave exposures.......................................................2

Figure 2. Mass change data for samples exposed to HWC for up to 9 months. Each data point is

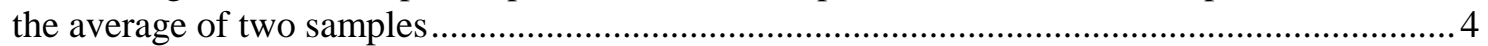

Figure 3. Mass change data for samples exposed to NWC for up to 9 months. Each data point is the average of two samples.

Figure 4. SEM cross-sectional micrographs of Gen-2 FeCrAl alloys after exposure to 3, 6, or 9 months in BWR-HWC $\left(290^{\circ} \mathrm{C}, 62 \mathrm{wppb} \mathrm{DH}\right)$. APMT and Zircaloy-2 exposed for 9 months are also shown for comparison.

Figure 5. SEM cross-sectional micrographs of Gen-2 FeCrAl alloys after exposure to 3, 6, or 9 months in BWR-NWC $\left(290^{\circ} \mathrm{C}, 1 \mathrm{wppm}\right.$ DO). APMT and Zircaloy-2 exposed for 9 months are also shown for comparison.

Figure 6. Box and whisker plot showing oxide thickness of FeCrAl alloys and Zircaloy-2 exposed for 3,6 , or 9 months to HWC

Figure 7. Box and whisker plot showing oxide thickness of FeCrAl alloys and Zircaloy-2 exposed for 3, 6, or 9 months to NWC

Figure 8. STEM-EDS of alloy C06M after 9 months in BWR-NWC $\left(290^{\circ} \mathrm{C}, 1 \mathrm{wppm} \mathrm{DO}\right)$.................... 10

Figure 9. STEM-EDS of alloy C35M after 9 months in BWR-NWC $\left(290^{\circ} \mathrm{C}, 1 \mathrm{wppm} \mathrm{DO}\right)$.................... 10

Figure 10. STEM-EDS of APMT after 9 months in BWR-NWC $\left(290^{\circ} \mathrm{C}, 1\right.$ wppm DO $)$......................... 10

Figure 11. STEM-EDS of alloy C06M after 9 months in BWR-HWC $\left(290^{\circ} \mathrm{C}, 63 \mathrm{wppb} \mathrm{DH}\right) \ldots \ldots \ldots \ldots \ldots . . .11$

Figure 12. STEM-EDS of alloy C35M after 9 months in BWR-HWC $\left(290^{\circ} \mathrm{C}, 63 \mathrm{wppb} \mathrm{DH}\right) \ldots \ldots \ldots \ldots \ldots \ldots . . . .11$

Figure 13. STEM-EDS of alloy C35MN6B after 9 months in BWR-HWC $\left(290^{\circ} \mathrm{C}, 63 \mathrm{wppb} \mathrm{DH}\right) \ldots \ldots \ldots .11$

Figure 14. STEM-EDS of APMT after 9 months in BWR-HWC $\left(290^{\circ} \mathrm{C}, 63 \mathrm{wppb} \mathrm{DH}\right)$....................... 12 
Figure 15. Raman spectra of FeCrAl samples exposed for 6 months to BWR-NWC $\left(290^{\circ} \mathrm{C}, 1\right.$ wppm DO) or BWR-HWC $\left(290^{\circ} \mathrm{C}, 63 \mathrm{wppb} \mathrm{DH}\right)$.

\section{TABLES}

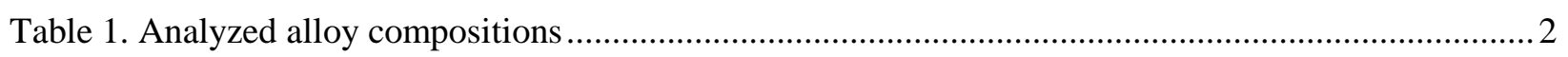




\section{Hydrothermal Corrosion of Second Generation FeCrAl Alloys in Boiling Water Reactor Conditions}

\section{INTRODUCTION}

As part of an industry-wide effort to replace Zircaloy fuel cladding with a material that does not undergo runaway oxidation at very high temperatures (accident tolerant fuel or ATF cladding), ironchromium-aluminum (FeCrAl) alloys have emerged as leading candidates[1,2]. Commercial FeCrAl alloys such as Kanthal APMT have been used in several industries and have excellent corrosion resistance in many conditions. In high temperature water, the alloys form a protective Cr-rich layer, and at high temperature when $\mathrm{Al}$ becomes mobile, they form a protective $\mathrm{Al}_{2} \mathrm{O}_{3}$ layer.

ORNL has developed nuclear-grade $\mathrm{FeCrAl}$ alloys specifically for use as ATF cladding. The development process is described in-detail in a prior work[3]. While the purpose of ATF cladding is improved corrosion performance during accident scenarios, any new cladding material must also demonstrate suitable corrosion performance during normal operating conditions.

The objective of this work is to observe the hydrothermal corrosion behavior of candidate $\mathrm{FeCrAl}$ alloys in BWR conditions. Candidate alloys were exposed to normal water chemistry (NWC) and hydrogen water chemistry (HWC) for 9 months, and corrosion behavior was characterized with scanning electron microscopy (SEM), Raman spectroscopy, and transmission electron microscopy (TEM).

\section{EXPERIMENTAL}

Corrosion coupons were prepared from several candidate $\mathrm{FeCrAl}$ alloys. The analyzed compositions in the current study are summarized in Table 1 . The alloy C06M contains nominally $10 \mathrm{wt} \% \mathrm{Cr}$, and the other alloys have nominally $13 \mathrm{wt}$.\% Cr. Minor alloying additions of molybdenum and niobium are intended to increase alloy strength. The former through solid-solution hardening and the latter through precipitate strengthening by the formation of $\mathrm{Fe}_{2} \mathrm{Nb}$ type Laves phase particles. Yttrium was also added to improve the oxidation resistance of the alloys at elevated temperatures. Further detailed alloy design strategy of the alloys can be found elsewhere[3]. The C06M was prepared by arc-melting and dropcasting into a water-jacket cooled copper mold to make a bar ingot with a size of $13 \times 25 \times 125 \mathrm{~mm}$. The other alloys were prepared by a vacuum induction melting (VIM) and casting into a graphite mold to make columnar ingots with a size of $81-86 \mathrm{~mm}$ in diameter $\mathrm{x} 300-560 \mathrm{~mm}$ in length. All ingots were homogenized at $1200^{\circ} \mathrm{C}$ in an argon gas atmosphere for up to $4 \mathrm{~h}$, followed by air cooling. Some of the VIM ingots were subjected to hot-forging at $1200^{\circ} \mathrm{C}$ to break the solidification microstructure. The ascast/forged ingots were sectioned into small pieces, hot-forged, and rolled at $800^{\circ} \mathrm{C}$ with $>90 \%$ total thickness reduction to make plate-form samples. The plate samples were then subsequently annealed at $800^{\circ} \mathrm{C}$ in laboratory air for $1 \mathrm{~h}$. The plates were further warm-rolled at $300^{\circ} \mathrm{C}$ with $5-10 \%$ thickness reduction per pass, for a total of 73-80\% thickness reduction, followed by air cooling. Coupons with a size of $12 \times 12 \times 1 \mathrm{~mm}$ were machined from the warm-rolled plates by electrical discharge machining (EDM), followed by grinding of all surfaces to remove the oxide layers, and polishing to a roughness of $<0.8 \mu \mathrm{m}$. A $1.6 \mathrm{~mm}$ diameter hole was drilled in each specimen for hanging in the autoclave, as shown in Figure 1. 
Table 1. Analyzed alloy compositions

\begin{tabular}{|c|c|c|c|c|c|c|c|c|}
\hline \multirow{2}{*}{ Name } & \multicolumn{7}{|c|}{ Analyzed composition, wt.\%* } & \multirow{2}{*}{ Remarks } \\
\hline & $\mathrm{Fe}$ & $\mathrm{Cr}$ & $\mathrm{Al}$ & Mo & $\mathrm{Nb}$ & $\mathrm{Y}$ & $\mathrm{Si}$ & \\
\hline $\mathrm{C} 06 \mathrm{M}$ & 81.8 & 10.0 & 6.00 & 1.96 & $<0.01$ & 0.010 & 0.18 & Arc-melted, $10 \mathrm{Cr}-6 \mathrm{Al}-2 \mathrm{Mo}$ \\
\hline C35M3 & 79.4 & 13.1 & 5.31 & 2.00 & $<0.01$ & 0.053 & 0.13 & VIM**, 13Cr-5Al-2Mo \\
\hline C36M3 & 78.8 & 13.0 & 6.00 & 1.98 & $<0.01$ & 0.040 & 0.18 & VIM, 13Cr-6Al-2Mo \\
\hline $\mathrm{C} 37 \mathrm{M}$ & 77.5 & 13.0 & 7.22 & 1.99 & $<0.01$ & 0.081 & 0.19 & VIM, 13Cr-7Al-2Mo \\
\hline C35MN6B & 78.7 & 13.0 & 5.11 & 1.99 & 0.96 & 0.044 & 0.18 & VIM, $13 \mathrm{Cr}-5 \mathrm{Al}-2 \mathrm{Mo}-1 \mathrm{Nb}$ \\
\hline
\end{tabular}

$* \mathrm{C}<50$ wppm, $\mathrm{S}<30$ wppm, $\mathrm{O}<26$ wppm, and $\mathrm{N}<4$ wppm, **VIM: Vacuum induction melted

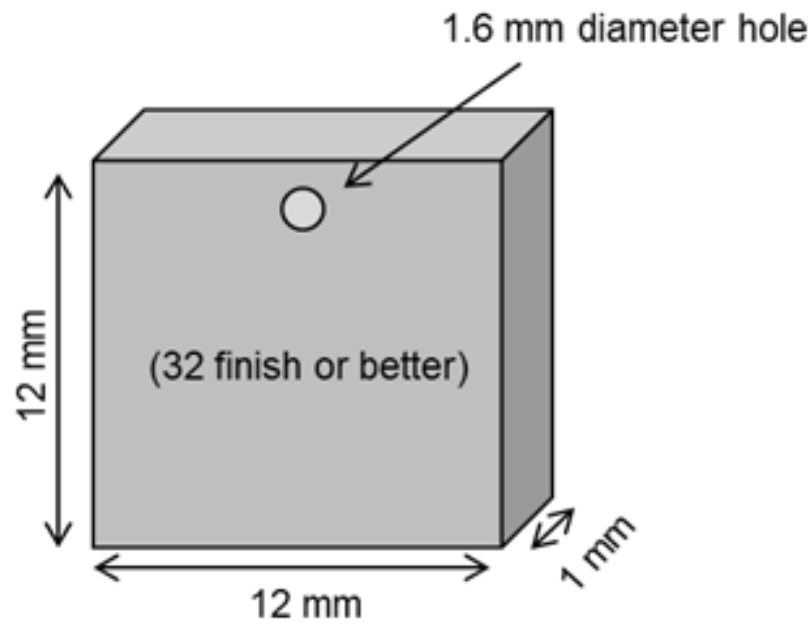

Figure 1. Drawing of the coupons used for autoclave exposures

Immersion tests were conducted for 9 months in two autoclaves, each containing pure water at $288^{\circ} \mathrm{C}$ with a pressure of $1300 \mathrm{psi}$. Intermediate mass measurements were taken at 3 months and 6 months. Autoclave $82 \mathrm{SK} 1$ contained pure water and a dissolved hydrogen $(\mathrm{DH})$ concentration of $63 \mathrm{ppb}$ at $288^{\circ} \mathrm{C}$, to emulate BWR-HWC. Autoclave 82SK6 had a dissolved oxygen (DO) at $288^{\circ} \mathrm{C}$ of $2000 \mathrm{ppb}$ to emulate BWR-NWC. In both systems, the stainless steels autoclaves had a capacity of 3.8 liters ( 1 gallon). Each autoclave had an independent water board with a vertical glass column of approximately 4 liters where water was continuously purged by a gas stream (oxygen in nitrogen for NWC or hydrogen in nitrogen for HWC). The conductivity of the water was constantly monitored at the inlet and outlet of the autoclaves. Water conductivity was monitored to be less than $<0.07 \mu \mathrm{S} / \mathrm{cm}$ at the inlet, with outlet conductivity nominally $<0.1 \mu \mathrm{S} / \mathrm{cm}$ in $\mathrm{HWC}$ and $<0.25 \mu \mathrm{S} / \mathrm{cm}$ in NWC. After exiting the autoclave, the water was cooled to ambient temperature, and was continuously filtered to remove dissolved ions. The pressure in the autoclave was controlled using a back-pressure regulator. The coupons of Zircaloy-2, APMT, C06M, C35M3, C36MC, C37M, and C35MN6B were suspended from a PTFE insulated wire in pure liquid water flowing at a flow rate of $100 \mathrm{cc} / \mathrm{min}$. The coupons were separated from each other using PTFE spacers.

After exposure, samples were weighed to determine mass change, and surfaces were examined with a Raman spectrometer with a laser wavelength of $632 \mathrm{~nm}$. Samples were metallographically mounted in epoxy, and cross sections were imaged with light microscopy and scanning electron microscopy (SEM) using a FEI-3400 FEG SEM. Oxide thickness was measured by taking 30 independent thickness measurements across the inner and outer oxides. TEM specimens were extracted using a focused ion beam (FIB). A FEI (now Thermo Scientific) Talos operating at $200 \mathrm{kV}$ was used to investigate the near 
surface microstructure using Scanning Transmission Electron Microscopy coupled with electron dispersive spectroscopy (STEM-EDS). EDS spectrum data cubes were collected with a 1024 x 1024 pixel size, with 60-minute live time acquisition/map, and a $2 \mathrm{nA}$ probe. STEM-EDS maps were completed with simultaneous high angle annular dark field (HAADF) and medium angle annular dark field (MAADF) acquisition. STEM-EDS/HAADF/MAADF triplet acquisition was drift corrected. Raw count maps for each element of interest and contrast images from the HAADF and MAADF detectors were extracted manually from the Bruker Quantax Espirit data acquisition and manipulation software. After extraction, raw count maps were binned to 512 x 512 pixels. Line profiles were extracted from the 512 x 512 pixels as indicated on the element count maps (e.g. line profiles are 1x512 pixels long).

\section{RESULTS}

Mass change is plotted for the APMT, Zircaloy-2, and candidate FeCrAl alloys in HWC and NWC in Figure 2 and Figure 3 respectively. Each data point represents the average of two identical samples. All samples lost mass in HWC. This was expected for the FeCrAl alloys, but previous works have found a mass gain for Zircaloy-2 in similar conditions [4-8]. In NWC, all materials were found to lose mass except C35MN6B and APMT. Mass losses were much smaller than in HWC, and for practical purposes, the mass gain and mass loss for samples exposed to NWC can be considered too small to draw significant comparisons between alloys. 


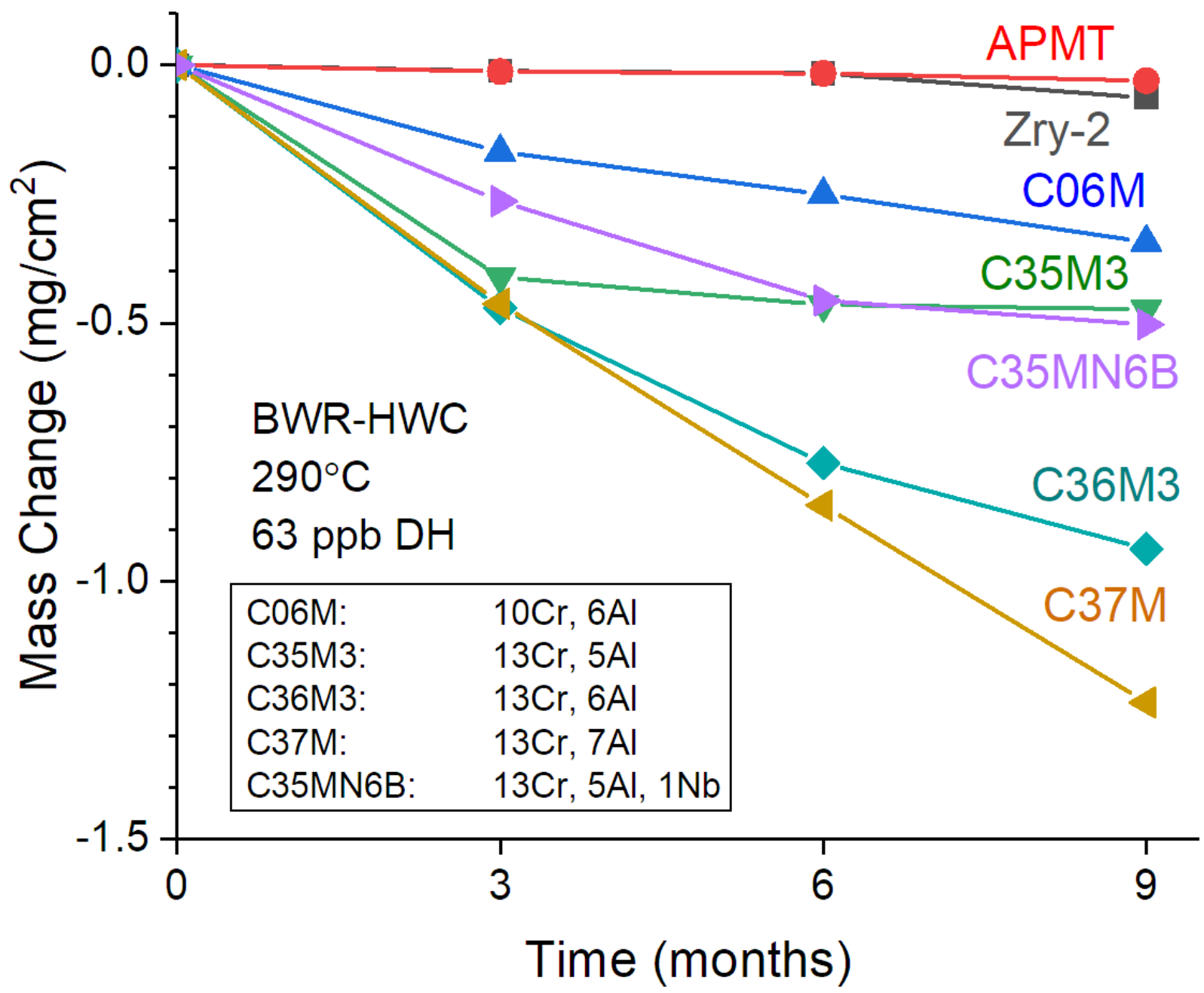

Figure 2. Mass change data for samples exposed to HWC for up to 9 months. Each data point is the average of two samples 


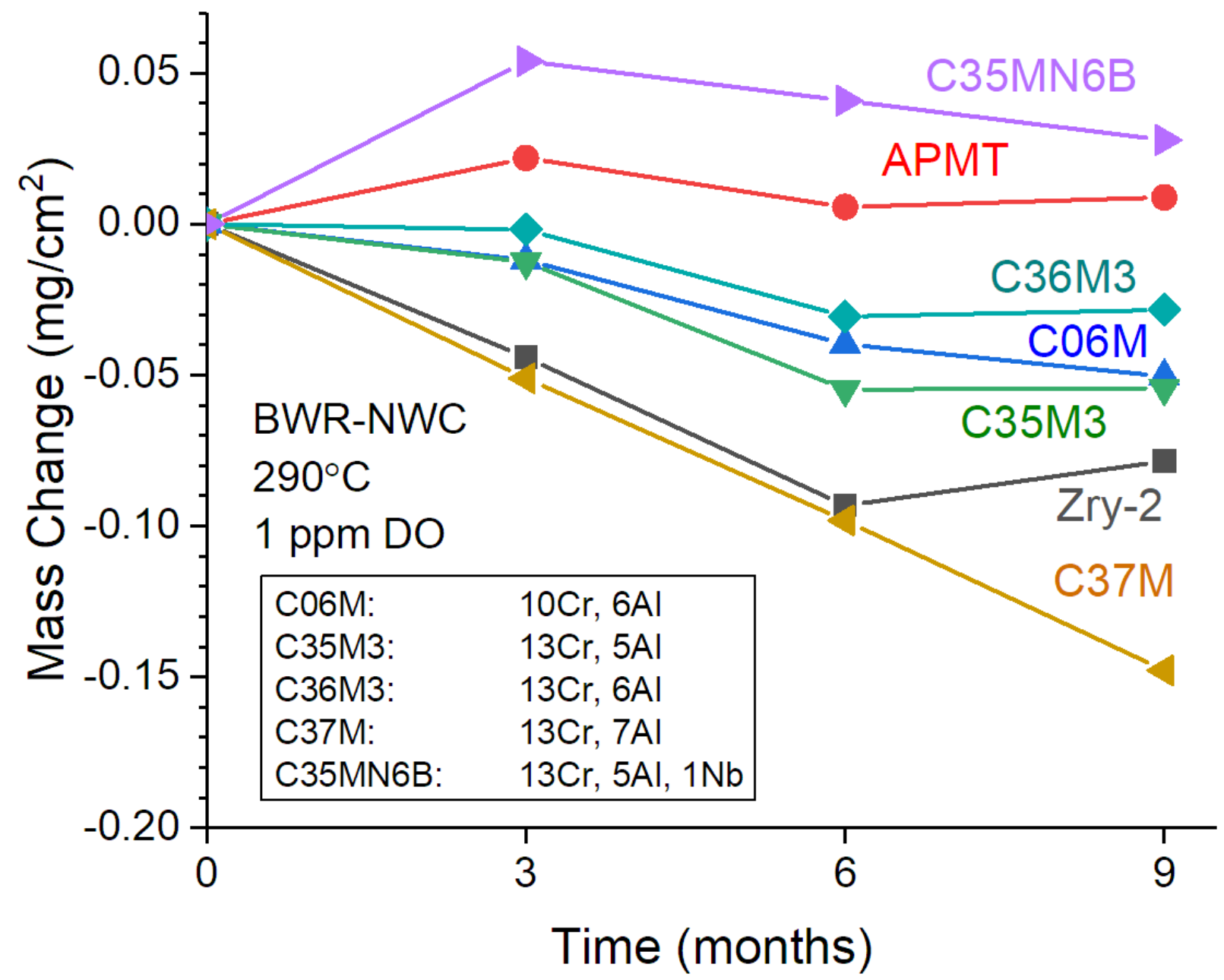

Figure 3. Mass change data for samples exposed to NWC for up to 9 months. Each data point is the average of two samples.

Samples were mounted metallographically, and SEM cross sections are shown in Figure 4 and Figure 5. 


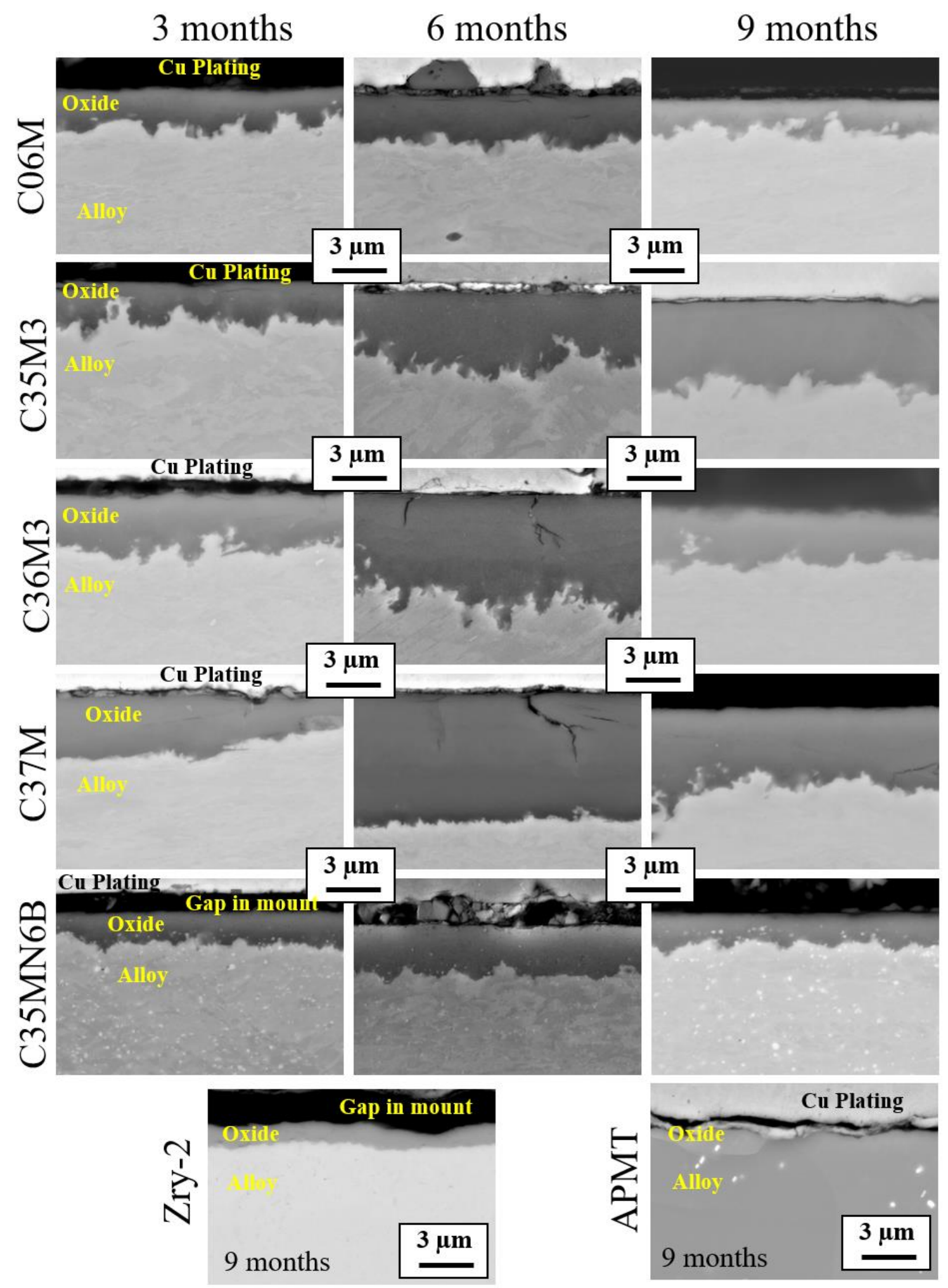

Figure 4. SEM cross-sectional micrographs of Gen-2 FeCrAl alloys after exposure to 3, 6, or 9 months in BWR-HWC $\left(290^{\circ} \mathrm{C}, 62 \mathrm{wppb}\right.$ DH). APMT and Zircaloy-2 exposed for 9 months are also shown for comparison. 


\section{3 months $\quad 6$ months $\quad 9$ months}

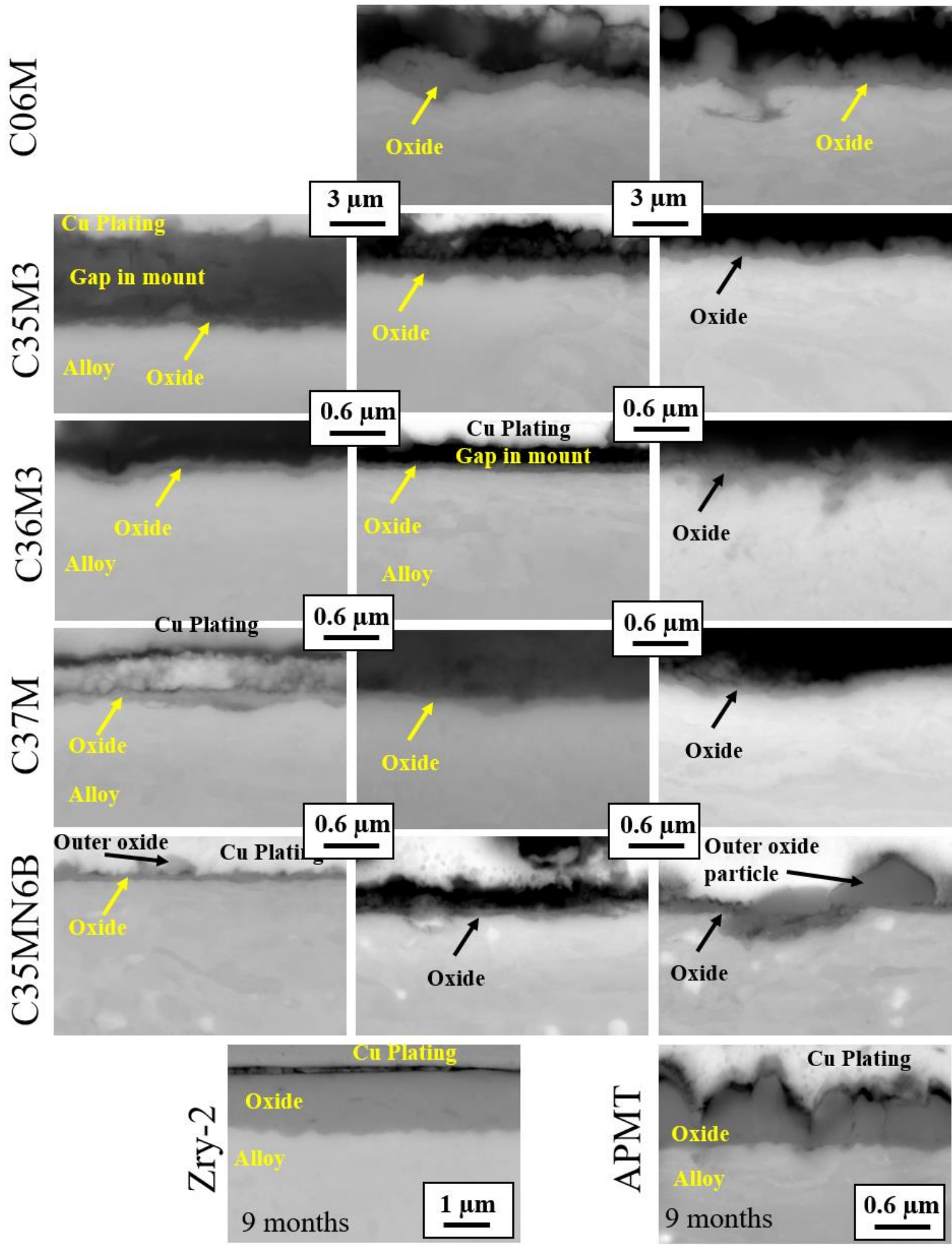

Figure 5. SEM cross-sectional micrographs of Gen-2 FeCrAl alloys after exposure to 3, 6, or 9 months in BWR-NWC $\left(290^{\circ} \mathrm{C}, 1 \mathrm{wppm}\right.$ DO). APMT and Zircaloy-2 exposed for 9 months are also shown for comparison. 
Oxide thickness was measured on samples exposed for 3, 6, and 9 months (one sample for each materialtime combination). Measurements were made at 30 different points on each mounted sample, and the results are shown in Figure 6 and Figure 7. For Zircaloy-2 and APMT, only samples exposed for 9 months were available, and for C06M, no 3 months sample was available.

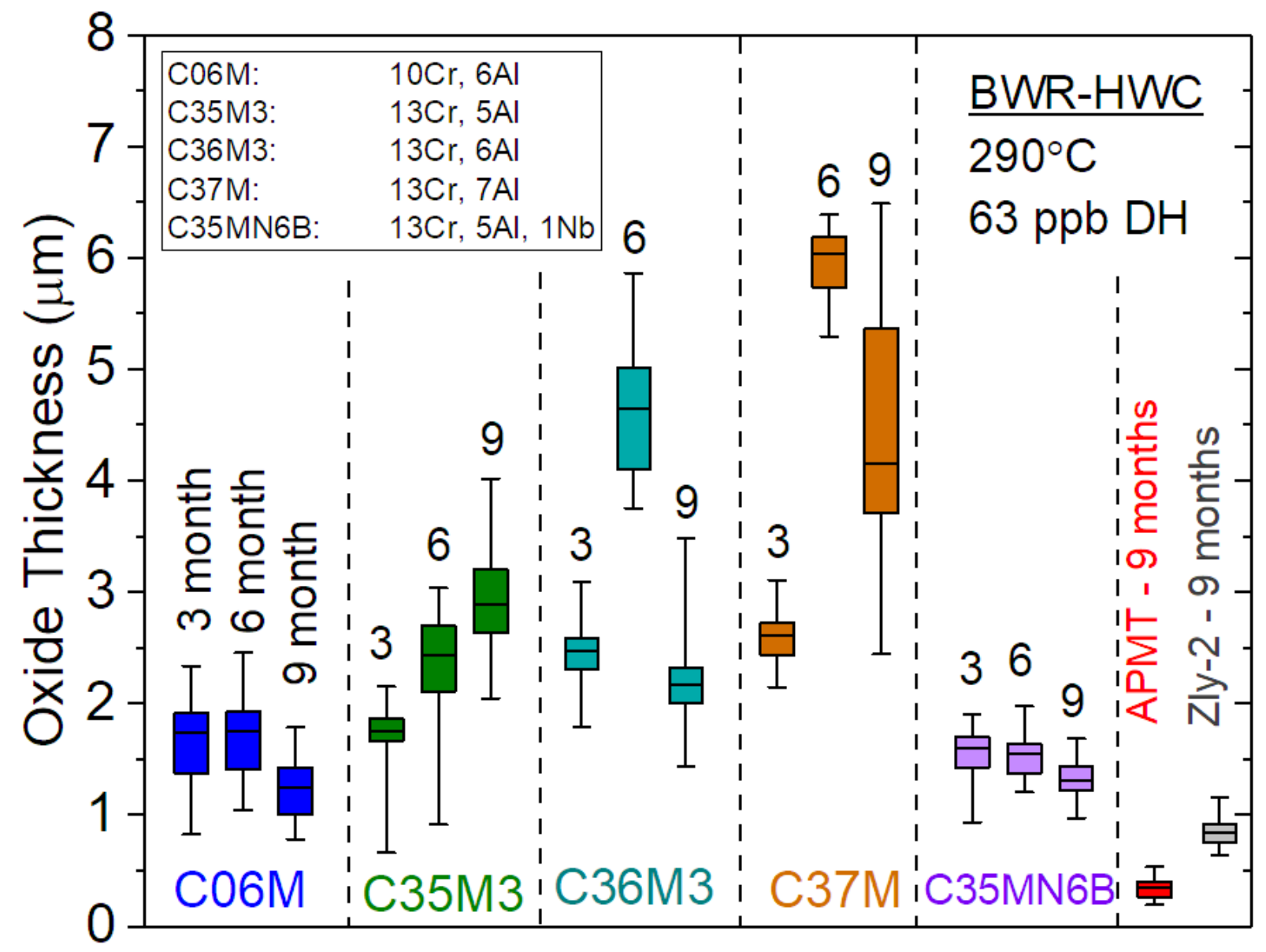

Figure 6. Box and whisker plot showing oxide thickness of FeCrAl alloys and Zircaloy-2 exposed for 3, 6, or 9 months to HWC 


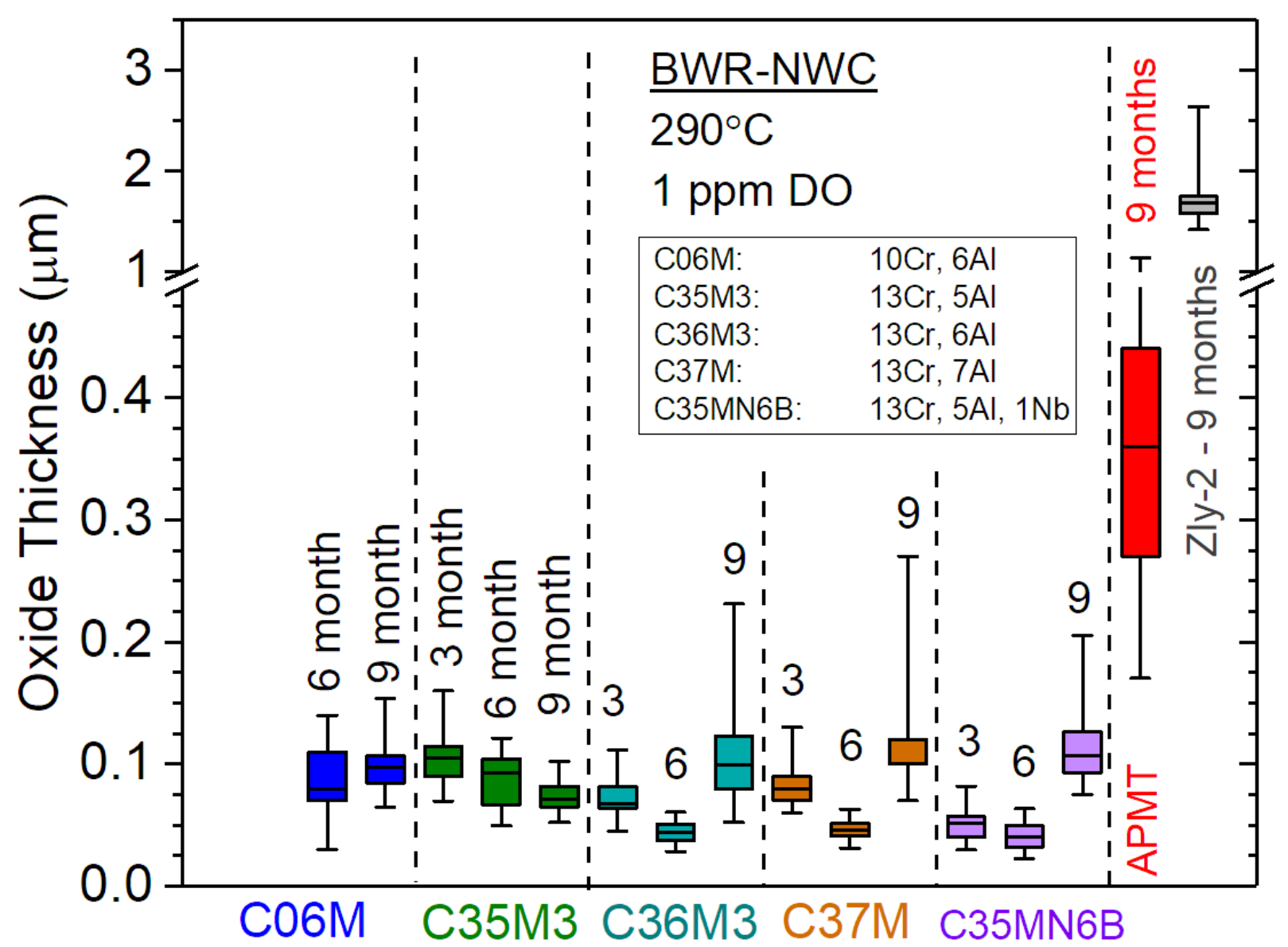

Figure 7. Box and whisker plot showing oxide thickness of FeCrAl alloys and Zircaloy-2 exposed for 3, 6, or 9 months to NWC

To understand the composition of the oxide films and the metal near the oxide interface, STEM-EDS micrographs are shown in Figures 8-14. Figures 8-10 depict samples C06M, C35M, and APMT, respectively, after exposure to NWC. In each case, a thin iron-rich oxide is visible on the sample surface. A region of $\mathrm{Cr}$ and $\mathrm{Al}$ enrichment is visible on Figure 9, although the oxide is thin enough that this may be anomalous, and no conclusions can be reasonably drawn from this observation without more corroborating data. Figure 11-14 show samples C06M, C35M, C35MN6B, and APMT after exposure to HWC. Except APMT in Figure 14, the oxides are noticeable thicker and richer in $\mathrm{Cr}$ than the oxides on samples exposed to NWC, although the increased Cr content may also be an artifact of the EDS scanning process on oxides with different thickness. Notably, the oxide on APMT exposed to HWC is much thinner than the oxides on other samples exposed to HWC, likely due to the significantly higher $\mathrm{Cr}$ content of the alloy when compared to the other alloys. 

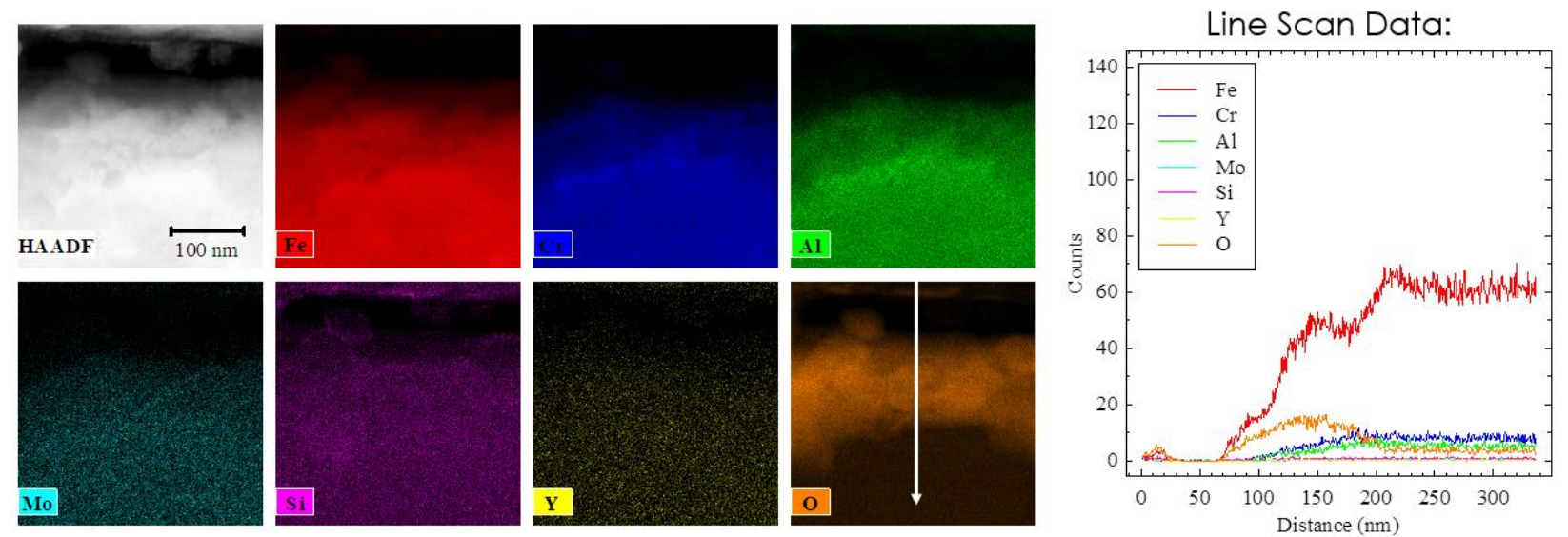

Figure 8. STEM-EDS of alloy C06M after 9 months in BWR-NWC $\left(290^{\circ} \mathrm{C}, 1 \mathrm{wppm}\right.$ DO).
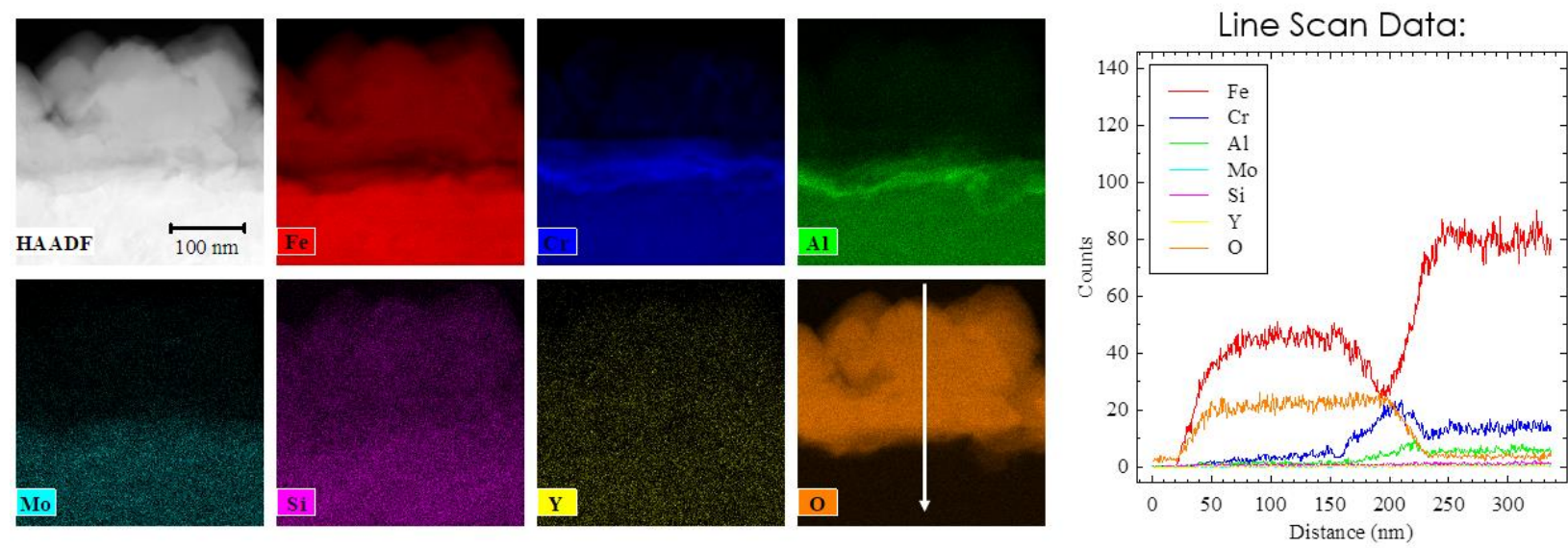

Figure 9. STEM-EDS of alloy C35M after 9 months in BWR-NWC $\left(290^{\circ} \mathrm{C}, 1 \mathrm{wppm}\right.$ DO).
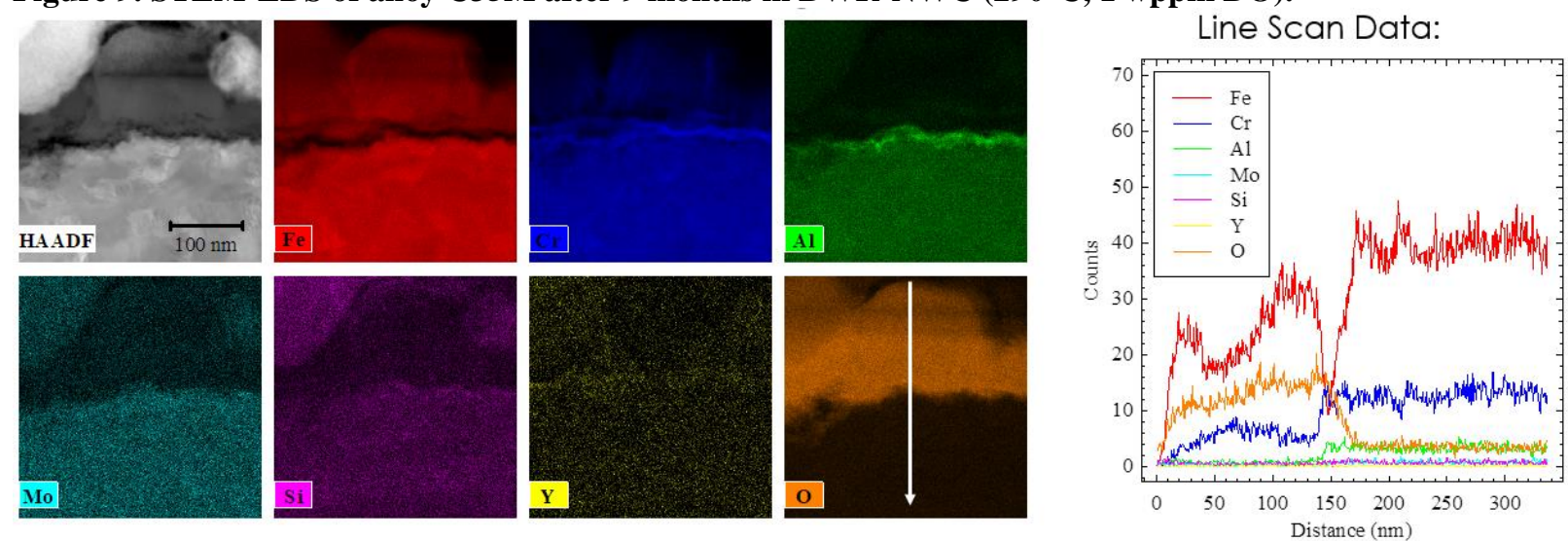

Figure 10. STEM-EDS of APMT after 9 months in BWR-NWC $\left(290^{\circ} \mathrm{C}, 1 \mathrm{wppm}\right.$ DO). 

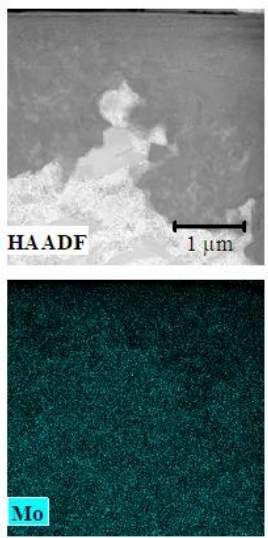
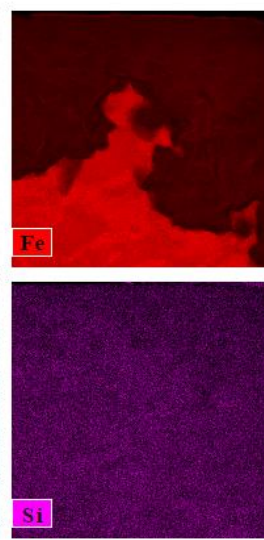
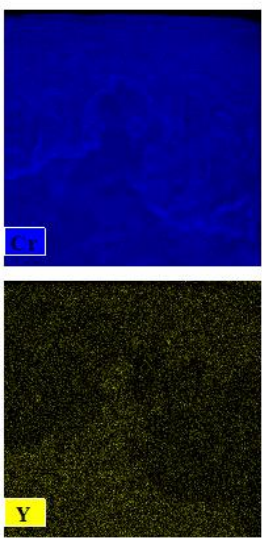
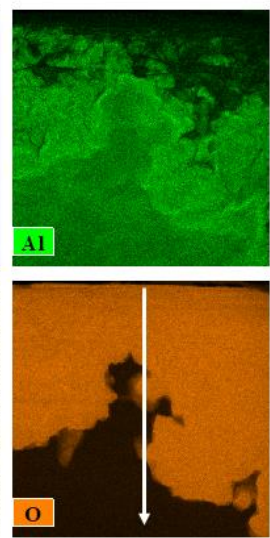

Line Scan Data:

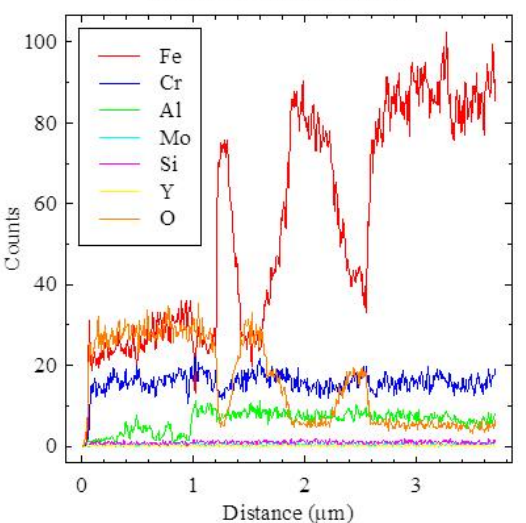

Figure 11. STEM-EDS of alloy C06M after 9 months in BWR-HWC $\left(290^{\circ} \mathrm{C}, 63 \mathrm{wppb} \mathrm{DH}\right)$.
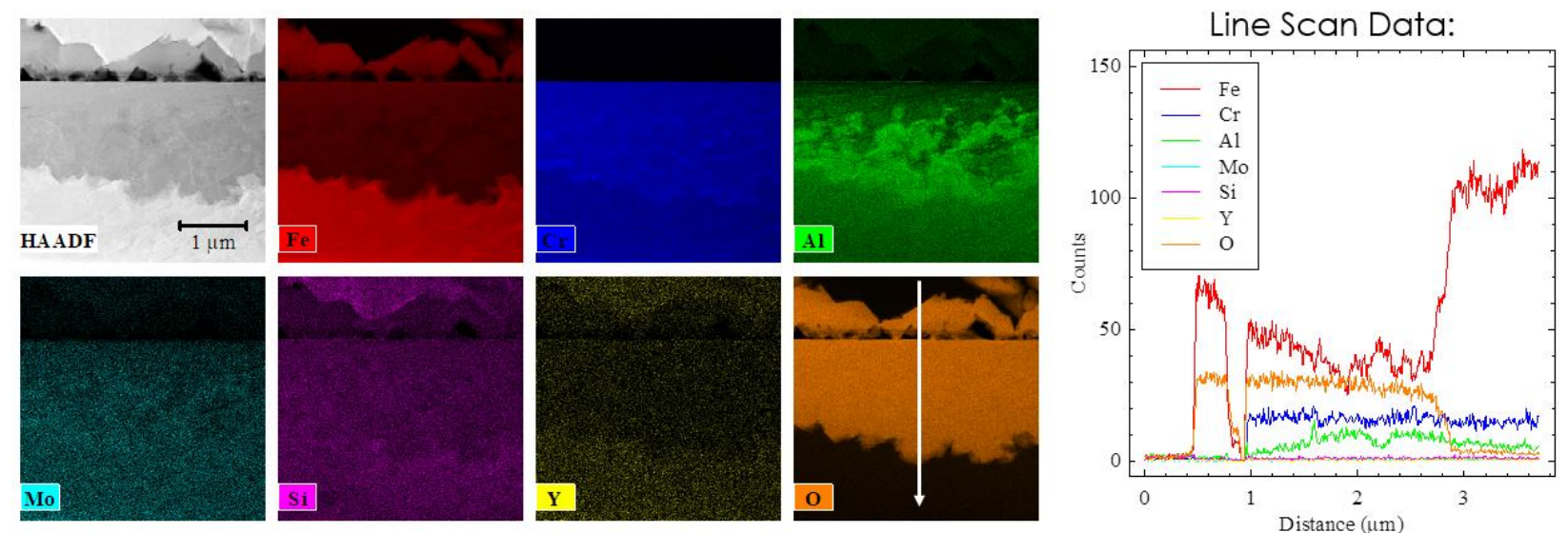

Figure 12. STEM-EDS of alloy C35M after 9 months in BWR-HWC $\left(290^{\circ} \mathrm{C}, 63 \mathrm{wppb} \mathrm{DH}\right)$.
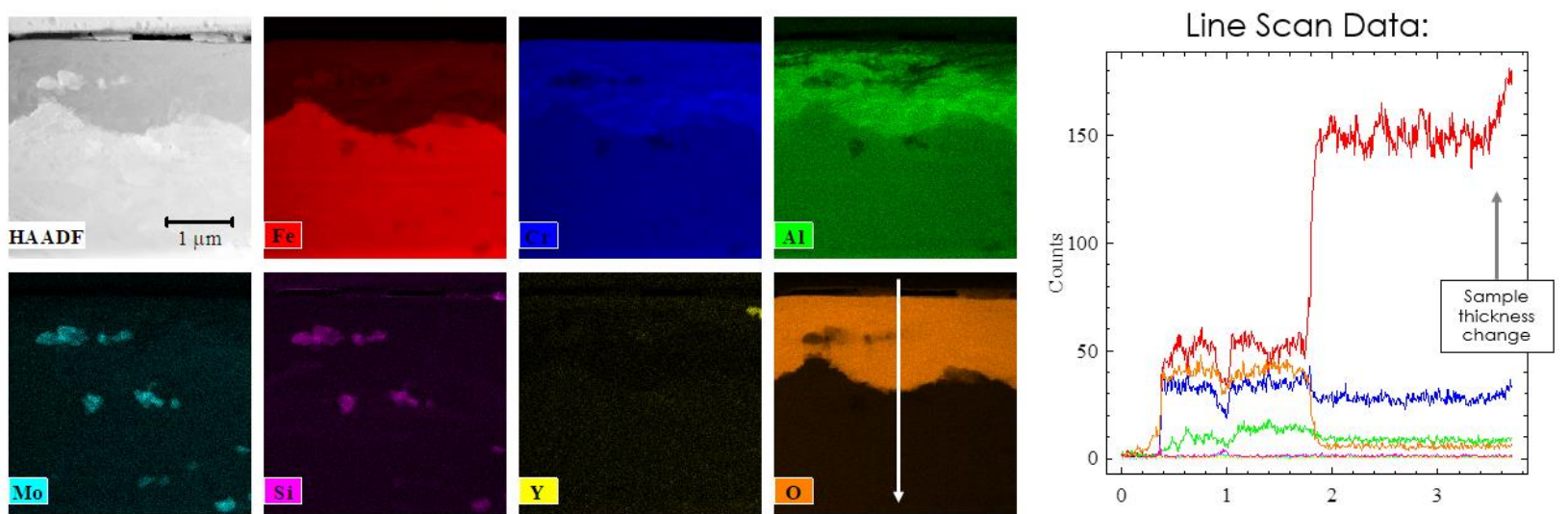

Figure 13. STEM-EDS of alloy C35MN6B after 9 months in BWR-HWC $\left(290^{\circ} \mathrm{C}, 63 \mathrm{wppb} \mathrm{DH}\right)$. 

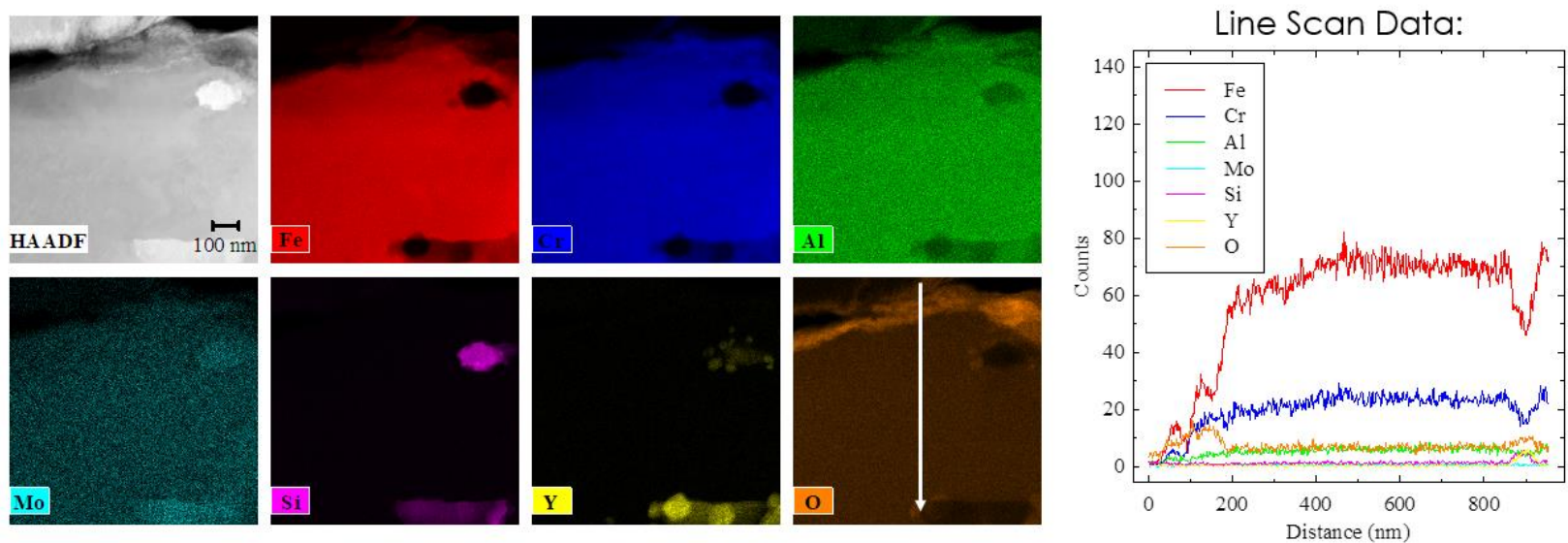

Figure 14. STEM-EDS of APMT after 9 months in BWR-HWC $\left(290^{\circ} \mathrm{C}, 63 \mathrm{wppb}\right.$ DH).

Samples exposed to NWC and HWC for 3 and 6 months were also characterized with Raman spectroscopy, and representative scans of the 6-month samples are shown in Figure 15 (spectra taken on 3-month samples were similar to 6-month samples). As expected [9-13], the samples exposed to HWC show mostly spinel-type oxides $\left(\mathrm{M}_{2} \mathrm{O}_{4}\right)$ on the surface, while samples exposed to NWC show a mix of hematite $\left(\mathrm{Fe}_{2} \mathrm{O}_{3}\right)$ and spinel oxides. The lone exception is alloy M35CMN6B, which also exhibited hematite on the surface in HWC. Thermodynamic calculations are in progress to understand if $\mathrm{Nb}$ can lead to increased stability of hematite. 


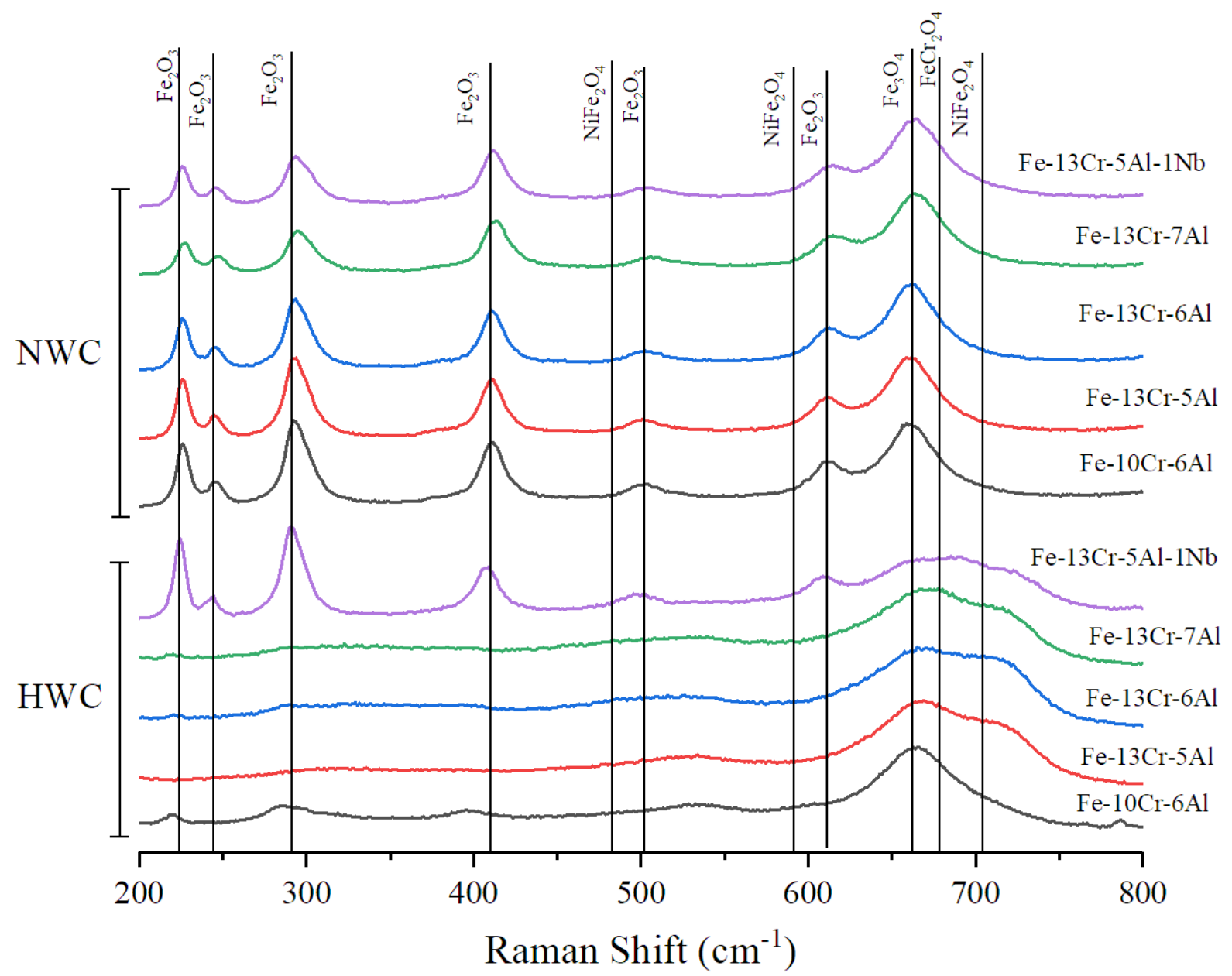

Figure 15. Raman spectra of FeCrAl samples exposed for 6 months to BWR-NWC $\left(290^{\circ} \mathrm{C}, 1 \mathrm{wppm} \mathrm{DO}\right)$ or BWR-HWC $\left(290^{\circ} \mathrm{C}, 63 \mathrm{wppb}\right.$ DH $)$.

\section{CONCLUSIONS}

Generation 2 alloys exposed to NWC displayed very low corrosion rates and can be consider suitable for use as structural materials in this environment. Alloys exposed to HWC had higher corrosion rates, but still performed similar to generation $1 \mathrm{FeCrAl}$ alloys [4], and the corrosion rates represent small losses of thickness, of approximately a few $\mu \mathrm{m}$ per year. This corrosion rate can be judged suitable for use in HWC environments. In future work, the corrosion rates will be quantified and compared to cladding thickness.

For samples exposed to HWC, the measured mass change results for the Gen-2 FeCrAl samples show an almost linear mass loss. Cross sectional microscopy in Figure 6 shows the oxide thickness for most samples either gaining or losing thickness, and the variation can likely be attributed to sample-to-sample variation. It can then be reasonably assumed that on average, oxide thickness of the FeCrAl samples remains vaguely constant after 6 months of exposure. TEM data does not show significant loss of any alloy components in the metal, so it can be concluded that mass loss is explained by a steady-state oxidation in which the oxide moves inward consuming metal, and concurrently dissolves or spalls at the oxide-solution interface.

While these data indicate suitability of FeCrAl for service in NWC and HWC, they must still be considered preliminary as the effects of radiation are not considered. Radiation has been shown to 
accelerate corrosion of iron-based alloys in LWR water[14-16], and must be considered before these alloys can be fully judged as suitable for use in-service. The very low corrosion rates shown in this study do suggest that even with a several-fold increase in corrosion rate in-pile, the corrosion rates will likely be low enough for service as LWR cladding.

\section{ACKNOWLEDGEMENTS}

The authors acknowledge the assistance of Traci Lowe and Tyson Jordan. The work presented in this paper was supported by the U.S. Department of Energy, Office of Nuclear Energy, Advanced Fuels Campaign. 


\section{REFERENCES}

1. Baldwin, C.A., et al., First elevated-temperature performance testing of coated particle fuel compacts from the AGR-1 irradiation experiment. Nuclear Engineering and Design, 2014. 271: p. 131-141.

2. Terrani, K.A., L.L. Snead, and J.C. Gehin, Microencapsulated fuel technology for commercial light water and advanced reactor application. Journal of Nuclear Materials, 2012. 427(1): p. 209224.

3. George, N.M., et al., Neutronics studies of uranium-bearing fully ceramic microencapsulated fuel for pressurized water reactors. Nuclear Technology, 2014. 188(3): p. 238-251.

4. Hunt, R., et al., Preparation of UC 0.07-0.10 N 0.90-0.93 spheres for TRISO coated fuel particles. Journal of Nuclear Materials, 2014. 448(1): p. 399-403.

5. Hunt, R., et al., Preparation of uranium fuel kernels with silicon carbide nanoparticles using the internal gelation process. Journal of Nuclear Materials, 2012. 427(1): p. 245-248.

6. Hunt, R.D., et al., Preparation of spherical, dense uranium fuel kernels with carbon. Radiochimica Acta, 2007. 95(4): p. 225-232.

7. Lindemer, T., et al., Quantification of process variables for carbothermic synthesis of UC 1-x $N x$ fuel microspheres. Journal of Nuclear Materials, 2017. 483: p. 176-191.

8. Lindemer, T.B., et al., Carbothermic Synthesis of 820- $\quad$ m UN Kernels: Investigation of Process Variables. 2015, Oak Ridge National Laboratory (ORNL), Oak Ridge, TN (United States).

9. McMurray, J.W., et al., Examination of viability of UN kernel production with additives such as SiC and B. 2017, Oak Ridge National Laboratory.

10. McMurray, J.W., J. Kiggans, and K. Terrani, Examination of HIP for production of high density UN kernels. 2017, Oak Ridge National Laboratory.

11. McMurray, J.W., et al., Production of Low Enriched Uranium Nitride Kernels for TRISO Particle Irradiation Testing. 2016, Oak Ridge National Laboratory (ORNL), Oak Ridge, TN (United States).

12. Brook, R., Additives and the sintering of ceramics. Sci. Sintering, 1988. 20(2): p. 115-118.

13. Carter, C.B. and M.G. Norton, Ceramic materials: science and engineering. 2007: Springer Science \& Business Media.

14. De Jonghe, L.C. and M.N. Rahaman, 4.1 Sintering of Ceramics. Handbook of Advanced Ceramics: Materials, Applications, Processing and Properties, 2003. 2: p. 187.

15. Harmer, M., Use of solid-solution additives in ceramic processing. Advances in ceramics, 1984. 10: p. 679.

16. Ebner, M., Chemistry Improvement for the Production of LEU UCO Fuel Using Manufacturing Scale Equipment-FY 2004 Final Report. Idaho: Idaho National Laboratory, 2004. 